\title{
1. Introduction: International Law is Fragmented and Cyclical
}

\section{THESIS OF THE BOOK}

This book deals with international trade and investment law at various levels of governance: unilateral, bilateral, regional, and multilateral. While multilateralism dominated international relations in the various fields of international economic law such as international trade law and international monetary law after World War II-thereby giving birth to the General Agreement on Tariffs and Trade (GATT)/Word Trade Organization (WTO) and to the International Monetary Fund (IMF), respectively-several attempts to establish a multilateral investment treaty have failed, as will be explained in Part 2 of this book.

The thesis of this book is that the nature of international law is fragmented and cyclical. At first, international trade agreements were bilateral. Then came the 1947 General Agreement on Tariffs and Trade, which multilateralized bilateral trade agreements. Years later, international trade law saw the collapse of multilateralism in 1979, which broke down during the Tokyo Round of multilateral trade negotiations. A series of new plurilateral (or selectively multilateral) agreements were adopted during the Tokyo Round, which caused a fragmentation of the multilateral trading system. ${ }^{\prime}$ In 1994, international trade law was again multilateralized with the World Trade Organization Agreement.

The same thesis could be used for international investment law. Given the success at multilateralizing international trade law-while not always easy, as analyzed in Part 1 of this book-why not emulate the experience of multilateralization of international trade law for international investment law? In the post-World War Il era, various States entered into bilateral treaties on commerce and navigation. These treaties were often called Friendship, Commerce and Navigation Treaties. As for bilateral investment treaties

\footnotetext{
${ }^{1}$ See Statement of the GATT Director-General on the Tokyo Round, April 12, 1979, 18 I.L.M. 553.
} 
(BITs), they are bilateral agreements typically between a rich and a poor country, which establish rights and protections for investors and a system to enforce those rights. The lack of a multilateral investment treaty has provoked a proliferation of BITs, resulting in what may be perceived to be fragmentation of international law.

A future multilateral framework on investment (MFI) would have many benefits. The need for an MFI can be perceived in the dramatic proliferation of international investment agreements in recent years. Many of these agreements have been concluded bilaterally, regionally, or even multilaterally. Different agreements oftentimes have different coverage of issues and may apply different rules. Separate negotiations increase the danger of inconsistent rules being established in different agreements. This leads to confusion, legal conflict, and uncertainty. ${ }^{2}$ In the WTO context, it could clarify the relationship among the General Agreement on Trade in Services, the Agreement on Trade-Related Investment Measures (TRIMs Agreement), and BITs. A future Multilateral Agreement on Investment (MAI) could also add substantive rules on environmental and labor standards to the current system of international investment law.

Furthermore, the current fragmented international investment regime may encourage regulatory competition among the various models of international investment agreements. Moreover, forum shopping and inconsistency of arbitral awards in dispute resolution seem to be the prime reasons why the creation of a multilateral framework for investment is necessary. It is therefore argued that there is a need for a coherent legal structure for the future of international investment law. If we agree that there are customary international law rules concerning investment, why not create an international framework that codifies the existing rules? Would this framework not serve to provide coherence, predictability, and legal security? Therefore, Part 2 of the book proposes the creation of a multilateral investment framework and studies the advantages of a multilateral investment system.

\section{LINK BETWEEN INTERNATIONAL TRADE AND INVESTMENT LAW}

Why write a book on international trade and investment law? Where is the link between international trade and international investment? A renewed interest in foreign direct investment (FDI) within the international trade

${ }^{2}$ Franck, S. "The Legitimacy Crisis in Investment Treaty Arbitration: Privatizing Public International Law Through Inconsistent Decisions," 73 Fordham Law Review, 1521 (2005). 
community has been stimulated by the perception that trade and FDI are simply two ways-sometimes alternative ways, but increasingly complementary - of servicing foreign markets, and that they are already interlinked in a variety of ways. ${ }^{3}$ For example, thanks to trade and investment, multinational companies may be able to specialize and produce more efficiently. International trade enables any given economy to specialize in a field in which it has a comparative advantage. FDI increases the international mobility of, and efficient use of, the world's supply of capital. Moreover, opening trade and investment is essential to overcoming economic crises such as the 2008 global financial crisis. ${ }^{4}$ Furthermore, authors like Kaberuka believe that it is trade and investment that can do most to end global poverty. ${ }^{5}$

There is indeed a link between international trade law and international investment law. For example, many enterprises do not just sell widgets across borders anymore. They also provide services, generate local goodwill, and/or utilize various forms of intellectual property as part of the process of selling their widgets.

So one can analyze how the various versions of the fair and equitable treatment (FET) standard may, or may not, provide an avenue for claimants to pursue damages for government actions that breach a WTO obligation and caused them loss or damage. On the FET standard, it is argued that a tribunal makes its determination on a case-by-case basis, where government conduct (or lack thereof) is considered in the totality of the circumstances. If those circumstances include conduct that could also be found in contravention of a WTO obligation, one could see how an investment treaty tribunal might be more inclined to find that the host State's conduct was also unfair and/or inequitable. This result would accrue especially in cases where the WTO's Dispute Settlement Body has already approved a panel report containing such findings of liability.

\footnotetext{
${ }^{3}$ See, e.g., Woolcock, S. (ed.) Trade and Investment Rule-Making: Role of Regional and Bilateral Agreements, Tokyo/New York: United Nations University Press, 2006; Woolcock, S. "The Role of Regional Agreements in Trade and Investment Regimes," UNU-CRIS Occasional Papers, O-2005/18, available at http://www.cris.unu.edu/fileadmin/workingpapers/20051205112905.O-2005-18.pdf.

${ }^{4}$ For official views on the 2008 global economic crisis, see International Monetary Fund, "Global Financial System Shows Signs of Recovery," available at http://www.imf.org/external/np/exr/key/finstab.htm and World Bank, "Financial Crisis," available at http://www.worldbank.org/financialcrisis/

s See Kaberuka, D. "If Doha dies, what then?" Europe's World, 6 November 2006, available at $\mathrm{http}: / \mathrm{www}$.europesworld.org/article.aspx?Id=61 cdbe44-561a-42ed-a0c2684a4b36b400\&VersionId=3beldf68-9fc7-4 196-ac90-bb68fl ad 7132
} 
The doctrinal basis for such an approach is obviously the principle of good faith, which must inform one's interpretation of any FET standard (indeed, it must inform one's interpretation of any treaty obligation). Investors are entitled to hold legitimate expectations that they and their investments will receive treatment that is consistent with any (and all) relevant international law obligations owed by the host State. It is not difficult to demonstrate that one's investment in Country $X$ was premised on an understanding that it would be acting in a manner consistent with its international obligations. Whether any given obligation would be relevant would depend upon the context of the dispute. For example, in the Glamis Gold v. USA case, ${ }^{6}$ the amicus submission from the Quechan Indian Tribe argued that the FET standard invoked by Glamis in its dispute with the USA could not be interpreted in abstraction from the extant international obligations owed by the USA to respect and preserve the rights and interests of indigenous peoples in the land that the frustrated investor had been seeking to mine for gold. Another example-this time hypothetical-would be the case of a drug patent holder who is not receiving a full 20 years of protection for its duly registered and used intellectual property rights. The fact that a WTO panel may already have found the host State in breach of its TradeRelated Aspects of Intellectual Property Rights (TRIPs) Agreement obligations with respect to the measure at issue would certainly be relevant within the context of an investment treaty dispute pursued to recover damages for the harm caused by such action (which is not recoverable in the WTO context).

In this regard, it does not seem to matter much whether one sees FET as either an autonomous standard or a crystallization of the minimum standard of treatment in customary international law, or both. The questionregardless of how or why the FET standard is being applied-is whether the circumstances of the case demonstrate that the FET standard has been breached. In other words, one is not arguing that a breach of a different international obligation satisfies the test for establishing that a breach of the FET obligation has occurred. Rather, one is concluding that the same factual matrix that supports the finding of a breach of a WTO obligation also supports the finding of a breach of the FET obligation. That a State should be expected to keep all of its promises (whether in place as a matter of convention or custom or principle) merely becomes part of the factual matrix for the FET analysis, because what constitutes "fair" and "equitable"

\footnotetext{
${ }^{6}$ For further information on the claim submitted to arbitration under the UNCITRAL Arbitration Rules, see Glamis Gold Ltd. v. United States of America, available at http://www.state.gov/s///c10986.htm.
} 
treatment must be informed by general principles of international law, such as the principle of good faith.

A further point to make is the debatable idea that just because most countries of the world are WTO Members, WTO obligations should be construed as candidates for inclusion in the corpus of customary international law. The WTO includes a lex specialis dispute settlement mechanism which should defeat this argument. The existence of a lex specialis dispute settlement mechanism demonstrates that, while WTO Members may claim to be bound to uphold WTO rules and act accordingly, they do so only with an understanding that failure to comply results in a specific set of remedies that-while perhaps similar to the customary international law rules on State responsibility-are not custom.

Another explanation of the link between trade and investment is the standard of review. The standards of review under WTO law and investment protection law are different. WTO law aims to protect the balance of concessions. That is why remedies are based on the suspension of benefits but not on the award of damages. Apart from that, parties to the WTO dispute resolution mechanism are States and the European Union but not private entities, although the latter are recognized as subjects at least under the Antidumping Agreement.

From the above, one could argue that monetary damages are clearly outside the present WTO system of dispute settlement. However, a violation of WTO standards might create a presumption of a violation of an applicable norm (e.g. TRIPs Agreement) even in an investment arbitration. This, however, would have to be examined on a case-by-case basis.

\section{STRUCTURE AND OVERVIEW OF THE BOOK}

There are three parts in this book: 1) international trade law, 2) international investment law, and 3) choice of jurisdiction-regional versus global jurisdiction-for the settlement of trade disputes. Each part is divided into various chapters.

\subsection{Part 1: International Trade Law and Policy}

With the delayed and stalled Doha Round of multilateral negotiation, multilateral trade governance seems to be in a stalemate. This, however, does not necessarily mean that the WTO is not doing its job. On the other hand, a growing number of bilateral and regional free-trade agreements (FTAs) are concluded for the purpose of enhancing trade and investment among the parties. This proliferation of FTAs has implications for multilateralism. For 
example, Mexico-Corn Syrup ${ }^{7}$ is at the intersection between multilateralism and regionalism.

Given the fragmentation of international trade law, Part 1 of this book analyzes the multilateral, regional, bilateral, and unilateral governance of international trade. For the analysis of unilateral trade measures, the European Union has been used as an example of unilateralism in international trade. For the bilateral governance of international trade, the European Union has also been used as a case study to examine its role and operations with Brazil, Russia, India, and China-the so-called BRIC countries, given the economic potential of these four emerging economies. In this sense, Part I analyzes the potential of trade partnerships of the EU with the so-called BRIC countries. Part 1 also analyzes the role of the EU and the BRIC countries in the multilateral trading system.

The scope of analysis in Part 1 has therefore been the EU vis-à-vis these countries, using three types of trade liberalization: unilateralism, bilateralism/regionalism, and multilateralism. The analysis of the EU with other equally economically important parts of the world, such as the United States or countries in the Asian/Pacific rim, is not part of this book's scope, even if countries in the Asian/Pacific rim (such as Japan, New Zealand, or Australia) have entered into a large number of international agreements facilitating trade and foreign direct investments.

It is argued that the EU's objective of engaging with the BRIC countries on trade matters is to establish peace, security, and prosperity in the $21 \mathrm{st}$ century. Trade creates economic ties and generates more wealth; thus it contributes to peace and security. It is also argued that there remains substantial scope for Brazil, China, and India to make further commitments towards greater liberalization within the services sectors and within all modes of supply provided in the General Agreement on Trade in Services. Finally, it is also argued that the attitude of the BRIC countries to multilateralism is unclear. The BRIC countries assume little responsibility to maintain international order in global economic governance. For example, China's role at the WTO has been rather passive since it joined in December 2001 and Russia withdrew from the Energy Charter Treaty in July 2009, refusing to live by its international commitments. India and Brazil do want to become more important players in world affairs, but they seem to lean against "traditional" powers (mainly the US), and tend to focus on South-South regionalism.

\footnotetext{
${ }^{7}$ Mexico-Anti-Dumping Investigation of High Fructose Corn Syrup (HFCS) from the United States, WT/DS132.
} 
In 2008 , in the midst of the most serious global economic crisis since the Great Depression, it seemed pertinent to reform the system of global economic governance. A Group of 20 nations (G-20), represented by their Finance Ministers and Central Bank Governors, succeeded the Group of 7 (G-7) in re-shaping the future of the global economic architecture. ${ }^{8}$ Part 1 addresses the importance of re-shaping the pillars of global economic governance, provides an analysis of the G-20 as the forum for such an initiative, acknowledges multipolarity and the rise of regionalism as the new global reality, and notes the lack of coordination between multilateral and regional mechanisms of economic governance.

Part 1 also tackles a complex binomial area of law and international relations, i.e., the European Union's external economic relations. The EU is certainly an economic giant, but remains a political gnome. This results in a bipolar power asymmetry; its representation in some international organizations such as the WTO and the Food and Agriculture Organization (FAO) is polycephalous in nature-since the European Union and its 27 Member States are members of the WTO and FAO, but not of the International Monetary Fund or the World Bank, where only countries are allowed for membership. ${ }^{9}$ This shows the EU's internal struggle for external presence.

\subsection{Part 2: International Investment Law and Policy}

Given the fragmentation of international investment law, Part 2 explores whether a multilateral investment treaty is necessary and possible in the framework of foreign direct investment (FDI) law or whether the current multifaceted and multilayered system of bilateral and regional investment agreements should be retained. Part 2 aims to study existing investment regimes with a view toward creating a multilateral investment framework. This goal, however, does not suggest that current bilateral and regional investment regimes should be replaced or that the existing regimes are inadequate. In addition, there is an analysis of foreign direct investment from

\footnotetext{
${ }^{8}$ Enrique Rueda-Sabater, Vijaya Ramachandran, and Robin Kraft have proposed objective criteria (population and GDP) for deciding which countries should join the club. See Rueda-Sabater, E., Ramachandran, V. \& Kraft, R. "A Fresh Look at Global Governance: Exploring Objective Criteria for Representation," Center for Global Development, Working Paper No. 160, Washington, D.C., February 2009.

${ }^{9}$ Leal-Arcas, R. "Polycephalous Anatomy of the EC in the WTO: An Analysis of Law and Practice," Florida Journal of International Law, Vol. 19.3 (2007), pp. 569-670; Leal-Arcas, R. "Will EU Member States Play Any Role at the WTO after the EU Reform Treaty?" Vienna Online Journal of International Constitutional Law, Vol. 1, lssue 2, pp. 75-90, 2007.
} 
an economic, development, and political perspective. Part 2 then reviews the chronological evolution of FDI regulation, followed by an overview of the current principles and rules of FDI.

As a necessary next step, it examines the support for a multilateral investment framework. The main reasons behind such a framework are twofold: the current fragmented and often uncoordinated international investment regime may encourage regulatory competition among the various models of international investment agreements; and investor-state arbitration is causing issues of inconsistency of arbitral awards as well as forum shopping in dispute resolution.

The investor-state arbitration mechanism is one of the most crucial elements of a sound investment regime. The investor-state dispute settlement mechanism can ensure investors that their investments are protected against arbitrary, discriminatory, and unfair government actions. Any changes to these provisions must strengthen and clarify the rights of investors abroad to encourage investment flows. Moreover, the importance of making investorstate arbitration available as a key part of a BIT does not depend on the quality of a BIT partner's legal system. Even if a country's legal system is highly regarded, the prospect of a foreign investor having to support its claim against the host government in a local court is a daunting prospect. It will require a reliance on local counsel and experts familiar with local procedures and customs. Even if the investor prevails, its judgment may be subject to multiple layers of appeal. And, even if the local judiciary is regarded as fair, the investor may well be trying its case in a hostile environment, which may affect the proceeding in subtle and unpredictable ways. The option of recourse to a neutral forum avoids these problems, giving the investor some assurance of having a reasonable chance at being compensated for any harm suffered.

Allowing the investor only to sue the host government at an international tribunal significantly shifts the balance in favor of companies and away from public interest and the right to regulate. Given the broad definition of investment, the loose definition of investor that still allows room for treaty shopping, and the strong protections of investors, this opens governmentsincluding the US government-to being sued for many ordinary regulations in the public interest. This can already be seen in the number of cases brought by investors against the US government under the North American Free Trade Agreement (NAFTA). Private corporations in one NAFTA country have the right to sue, through an investment arbitration process, the national government of another NAFTA party for cash compensation in closed trade tribunals over regulatory costs, which is contained in NAFTA's Chapter 11 on investment. NAFTA's innovative Chapter 11 is analyzed in Part 2. 
Finally, Part 2 identifies policy considerations for a future multilateral investment framework. Part 2 concludes that the WTO has the opportunity here to incorporate years of experience of bilateral and regional investment agreements and develop a multilateral agreement for investment. Such an agreement in the WTO context would not replace current investment regulatory regimes, but could clarify the relationship among the General Agreement on Trade in Services, the Agreement on Trade-Related Investment Measures, and bilateral investment treaties.

The failed attempts at establishing multilateral rules for investment (i.e., the Multilateral Agreement on Investment in 1998, the Cancún WTO Ministerial Conference of 2003) seem to have accelerated the move toward bilateral and regional promotion and protection of foreign investment. The increasing number of investor-state arbitrations may support the view that, at least for the time being, bilateral and regional governance of investment through BITs and investment chapters of FTAs will be a prevailing means of governing foreign investment. Moreover, the presence of a treaty enables the investor to pursue more meaningful discussions with a host government and settle most disputes on an equal basis. This is an important point that cannot be overemphasized. However, accumulation of investor-state arbitration is causing issues of conflicting arbitral awards and forum shopping that needs coordination at the multilateral level. Hence the importance of coordination at the multilateral level toward the creation of a multilateral investment treaty. So would it make sense to have a multilateral framework for investment (MFI)? An MFI would not only support FDI, it would also advance economies' competitiveness. Moreover, an MFI would lead to a more coherent international investment framework.

\subsection{Part 3: Choice of Jurisdiction for the Settlement of Trade Disputes}

One of the logical consequences of fragmentation of international (trade and investment) law is the proliferation of fora for the settlement of (trade and investment) disputes and the choice of jurisdiction when solving international disputes. ${ }^{10}$ Parties may choose to appear before a regional or global judicial body. For example, international trade law offers the WTO's dispute settlement mechanism at the global level, whereas at the regional level there is the dispute settlement mechanism of the North American Free Trade Agreement, the Association of Southeast Asian Nations, Mercosur, and the European Union inter alia. In the case of international investment law, there

${ }^{10}$ Teitel, R. \& Howse, R. "Cross-judging: Tribunalization in a Fragmented but Interconnected Global Order," NYU Journal of International Law and Politics, Vol. $41: 4,2009$. 
are also various fora for the settlement of disputes. For example, the International Centre for Settlement of Investment Disputes, the International Court of Justice, the International Chamber of Commerce, the London Court of International Arbitration, and the Permanent Court of Arbitration inter alia.

Different choices bring different results. In Mercosur, when a party decides to bring a case before its dispute settlement system, that party cannot bring the same case before the WTO Dispute Settlement System. Remedies make a considerable difference when choosing a regional versus a global dispute settlement system. Typically, the WTO's dispute settlement system is more effective in its implementation than would be the case of a regional dispute settlement system such as Mercosur. On the other hand, the WTO is much slower and more expensive than its regional South American counterpart.

An interesting example on trade remedies law of a choice of jurisdiction because of fragmentation of international law is the quasi-WTO/quasi-arbitral inter-state dispute filed by the US against Canada under the Softwood Lumber Agreement. ${ }^{11}$ Although a state-to-state dispute, the Softwood Lumber Arbitration was adjudicated under the auspices of the London Court of International Arbitration, which is more commonly used for commercial arbitration. This is due partly to the fact that the Softwood Lumber Agreement was a "mutually agreed solution" under Article 3.6 of the WTO Dispute Settlement Understanding (DSU). ${ }^{12}$ Although the WTO context of the Softwood Lumber Agreement is clear, and the parties' notification to the WTO Dispute Settlement Body of the mutually agreed solution included the full text of the Softwood Lumber Agreement, under conventional wisdom, "mutually agreed solutions" in the WTO cannot be enforced by the WTO's own dispute settlement system. Hence the need for outside arbitration.

The scope of analysis in Part 3 is only on international trade law. Part 3 will provide a legal and policy analysis of two fora for the settlement of international trade disputes, namely the NAFTA and the WTO, for countries that have standing in both jurisdictions, i.e., the United Mexican States, the United States of America, and Canada. Part 3 is, therefore, not on NAFTA's innovative Chapter 11 system of investment arbitration, which is analyzed in Part 2 and for which NAFTA sets the global standard. It is not the scope of

1 Softwood Lumber Agreement between Canada and the US, available at http://www.international.gc.ca/controls-controles/assets/pdfs/softwood/SLA-en.pdf.

${ }^{12}$ Article 3.6 DSU reads: "Mutually agreed solutions to matters formally raised under the consultation and dispute settlement provisions of the covered agreements shall be notified to the DSB and the relevant Councils and Committees, where any Member may raise any point relating thereto." 
Part 3 to see whether, or to what extent, the proposed creation of a multilateral agreement on investment analyzed in Part 2 of the book would affect the development of investor-state dispute settlement in the NAFTA. Therefore, the focus in Part 3 will only be on the NAFTA's Chapter 20 disputes and the WTO.

Both the WTO and NAFTA are judicially compared from the perspective of the respondent and of the complainant, analyzing the advantages and disadvantages of each forum. The chosen time-frame of judicial analysis is between 1995 and 2001. Unlike the WTO, which has an integrated dispute settlement system, the NAFTA's enforcement mechanisms are contained in five separate dispute settlement mechanisms: ${ }^{13}$

1. the government-to-government dispute settlement system, under Chapter 20;

2. the bi-national panels for adjudication of anti-dumping and countervailing duty measures, under Chapter 19;

3. various sector-specific measures (such as Chapter 11 for investment) for arbitration and/or dispute resolution, including more specific consultation for processes;

4. the use of national adjudication systems, especially for intellectual property and government procurement disputes; and

5. dispute resolution for the side agreements on labor and environmental issues.

For adequate comparison with the parallel WTO's dispute settlement measures, Part 3 of this book focuses on the sole dispute settlement mechanism within the NAFTA that consists of government-to-government disputes, and which pertains to the "avoidance or settlement of all disputes between the Parties regarding the interpretation or application of the Agreement. . .."14 The other dispute settlement mechanisms-for example, under Chapter 19 and Chapter 11, pertaining to anti-dumping and countervailing duties, and investment measures, respectively-allow the involvement of private parties from the NAFTA countries to be party to the dispute settlement proceedings.

${ }^{13}$ Gabrielle Marceau, "The Dispute Settlement Rules of the North American Free Trade Agreement: A Thematic Comparison with the Dispute Settlement Rules of the World Trade Organization," in Ernst-Ulrich Petersmann (ed.), International Trade Law and the GATT/WTO Dispute Settlement System, London; Boston: Kluwer Law International 489 (1997), at 495.

${ }^{14}$ NAFTA Article 2004. For the jurisdiction of the Chapter 20 dispute settlement mechanism, see Annex 2004 following in the text. 
Part 3 concludes with two cases which could have been brought in either forum, Broomcorn ${ }^{15}$ and Canada-Patent Term, ${ }^{16}$ and recommends that, for the future, the Party concerned in international trade disputes would need to look at the factors compositely on a case-specific basis to determine whether a dispute should be brought under the WTO or the NAFTA.

${ }^{15}$ US Safeguard Action Taken on Broomcorn Brooms from Mexico (USA-97-200801); NAFTA Panel decision, January 30, 1998.

${ }^{16}$ Canada-Term of Patent Protection, WT/DS170. 